\title{
Dose Analysis of BNCT Treatment Method for Rhabdomyosarcoma in the Head and Neck Regions Based on PHITS Code
}

\author{
Dhani Nur Indra Syamputra ${ }^{1, *}$, Yohannes Sardjono², and Rida Siti Nur'aini Mahmudah ${ }^{1}$ \\ ${ }^{1}$ Department of Physics, Faculty of Mathematics and Natural Sciences, Universitas Negeri Yogyakarta, Yogyakarta 55281, Indonesia \\ ${ }^{2}$ Center of Accelerator Science and Technology, National Nuclear Energy Agency, Yogyakarta 55281, Indonesia \\ *Corresponding author: dhaninurindrasyam@gmail.com
}

\author{
KEYWORDS \\ BNCT \\ Boron dose \\ Kartini Reactor \\ PHITS \\ Rhabdomyosarcoma
}

\begin{abstract}
The objectives of this research were to find (1) the optimum boron dose for treating rhabdomyosarcoma in the head and neck regions and (2) the effective irradiation time to treat rhabdomyosarcoma in the head and neck regions. This research used the particle and heavy ions transport code system (PHITS) to simulate the neutron source and BNCT doses. The neutron source used was Kartini Reactor. The simulation was carried out by creating the geometry of cancer tissue in the head and neck regions. Boron concentration variance was $30,35,40,45$, and $50 \mu \mathrm{g} / \mathrm{g}$ tissue. The output of PHITS was a neutron flux and neutron dose. The neutron flux value was used to acquire the alpha dose, proton dose, and gamma dose inside the tissue. The results showed that (1) the optimum boron dose for treating rhabdomyosarcoma in the head and neck regions was $50 \mu \mathrm{g} / \mathrm{g}$ tissue and (2) the effective irradiation time was 7 hours and 4 minutes, which was acquired with a boron concentration of $50 \mu \mathrm{g} / \mathrm{g}$ tissue. The higher the boron concentration level, the higher the dose rate, the quicker the irradiation time, and the lower the radiation dose received by healthy tissues.
\end{abstract}

(c) The Author(s) 2018. This article is distributed under a Creative Commons Attribution-ShareAlike 4.0 International license.

\section{INTRODUCTION}

Cancer is the second-leading cause of mortality all over the world. According to Stewart and Wild (2014), the cancer incidence rate reached 14.1 million new cases, while the death rate caused by cancer reached 8.2 million. Cancer in Indonesia caused 103,100 men and 92,200 women to die.

Cancer can occur at any age. In children cancer, can occur in ages $0-15$ years. The most common types of cancer in children are leukaemia, brain and spine, neuroblastoma, Wilms tumour, rhabdomyosarcoma, retinoblastoma, and bone cancer. Rhabdomyosarcoma is the most malignant soft tissue tumour in childhood (El Demellawy et al. 2017). The primary sites of rhabdomyosarcoma are $40 \%$ in the head and neck region, $24 \%$ in the genital region, $19 \%$ in the extremities, and $22 \%$ in other regions (Radzikowska et al. 2015; Reilly et al. 2015; Lee et al. 2017). Cancer treatment in the head and neck regions needs special attention to surrounding organ functions and the aesthetics of the head and neck itself.

The common methods to treat cancer are surgery, chemotherapy, radiotherapy, immunotherapy, and gene therapy. Surgery has become one of the most used methods to treat cancer. However, surgery can be done only if the tumour is localized and well differentiated from healthy tissue. According to Aihara et al. (2014), surgery method has negative side which can cause loss of physiological function and aesthetics of the organ, because surgery is related to partial or total amputation of an organ. Chemotherapy methods use drugs to shrink and treat cancer. Chemotherapy has side effects for the patients, such as hair loss, loss of hearing, and loss of cognitive function (Winocur et al. 2012; Smith and Prewett 2017; Miaskowski et al. 2018).

Boron Neutron Capture Therapy (BNCT) is one of radiotherapy methods which is being developed. BNCT use boron atoms, which are concentrated in the cancerous tissue with thermal neutrons to kill the cancer (Barth et al. 2012; Sauerwein et al. 2012; Rosidah et al. 2017). The reaction between boron with thermal neutrons produces lithium atoms and alpha particles that have high linear energy transfer (LET). Alpha particles have high ionization power, but can penetrate only 4-10 $\mu \mathrm{m}$ (Moss 2014). Therefore, BNCT can damage cancer cells without causing damage to other healthy cells.

BNCT needs treatment planning before therapy. The treatment planning needed is for the neutron source and boron drug dose injected into the patient. In Indonesia, the neutron source that can be used for BNCT is the Kartini Research Reactor at PSTA BATAN Yogyakarta. The Kartini reactor can produce thermal and epithermal neutron flux according to the standard for BNCT treatment (Sardjono et al. 2016; Rosidah et al. 2017).

$$
\begin{array}{r}
{\left[{ }_{5}^{10} B\right]+\left[{ }_{0}^{1} n\right] \longrightarrow\left[{ }_{5}^{11} B\right]^{*}-\begin{array}{l}
{\left[{ }_{2}^{4} \mathrm{He}\right]+\left[{ }_{3}^{7} \mathrm{Li}\right]+2.79 \mathrm{MeV}(6.1 \%)} \\
\longrightarrow\left[{ }_{2}^{4} \mathrm{He}\right]+\left[{ }_{3}^{7} \mathrm{Li}\right]^{*}+2.31 \mathrm{MeV}(93.9 \%)
\end{array}} \\
\longleftrightarrow\left[{ }_{3}^{7} \mathrm{Li}\right]+\gamma(0.48 \mathrm{MeV})
\end{array}
$$

FIGURE 1. ${ }^{10} \mathrm{~B}(\mathrm{n}, \alpha)^{7} \mathrm{Li}$ interactions. 
Dose determination for BNCT can be done using simulation of the cancer and body tissue of the patients to receive therapy. The Monte Carlo method is one of the most used simulation methods in nuclear physics because of its random characteristics similar to the nature of particles. Particle and heavy ions transport code systems (PHITS) is one of many softwares that can calculate using Monte Carlo method. PHITS has some advantages compared to the other software, namely that more particles can be calculated and use a wider energy span up to $3 \mathrm{GeV}$.

\section{MATERIALS AND METHODS}

\subsection{PHITS simulation}

This research was conducted using simulation methods by PHITS software. Building head and neck models was necessary before the BNCT simulation.

The head and neck model constructed was based on the standard geometrical size for a 5 year old child made by Cristy and Eckerman (1987). Tissue composition was taken from International Commission on (ICRU). Material composition data were taken through the National Institute of Standard and Technology (NIST) (NIST n.d.).

Cancer tissue was defined as a spherical ball placed on the back-left side of the head and neck (Figure 2). The cancer tissue was divided into three volumes, namely the gross tumour volume (GTV), clinical tumour volume (CTV), and planning tumour volume (PTV). The radii for each volume were $1.5 \mathrm{~cm}, 2.0 \mathrm{~cm}$, and $2.5 \mathrm{~cm}$. Material composition for PTV was the same as the material composition of healthy tissue, and the material composition for GTV and CTV was as listed in Table 1.

The boron atom was found only in cancer tissues. The boron concentrations used in this research were 30, 35, 40, 45 , and $50 \mu \mathrm{g} / \mathrm{g}$. The boron concentration inside cancer tissue GTV, CTV, and PTV respectively $80 \%, 10 \%$, and $5 \%$ of total boron concentration in cancer.

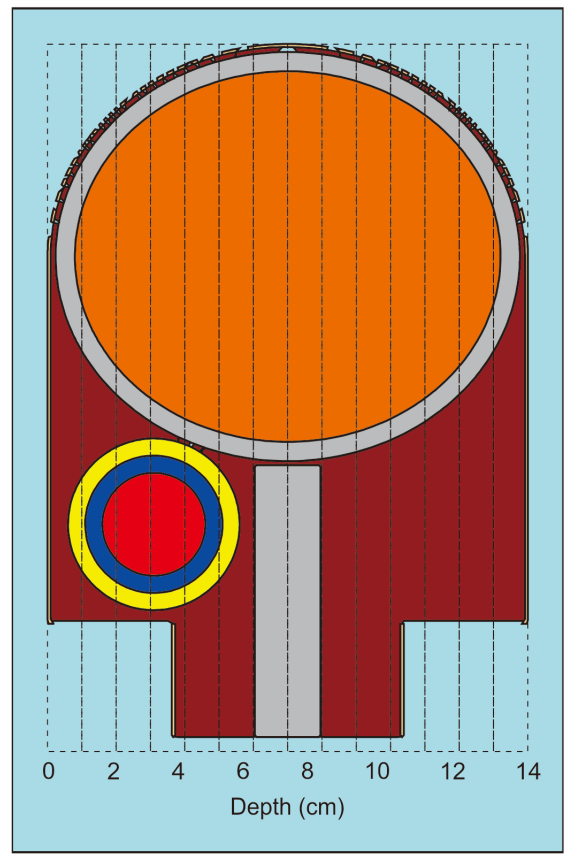

(a)

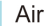
Skin

Soft Tissue
TABLE 1. Mass fraction for cancer tissue.

\begin{tabular}{lll}
\hline Atom & PHITS code & Mass fraction \\
\hline H & 1001 & 0.099 \\
C & 6012 & 0.269 \\
N & 7014 & 0.045 \\
O & 8016 & 0.569 \\
P & 15031 & 0.018 \\
\hline
\end{tabular}

BNCT needs a neutron source as a projectile to be fired at the cancer cells. In this research, the neutron source was the output from Kartini Reactor's radial piercing beam port that went through collimation by the research from Arrozaqi (2013). PHITS use the Monte Carlo method in its calculation. The result of the calculation was user defined using Tally function. The tally types used in this research were T-Track and T-Cross. T-Track gave the neutron absorbed dose data in the tissue, while T-Cross produced the value of neutron flux in depth of the tissue.

\subsection{Data analysis}

The PHITS simulation provided the data of absorbed dose in tissue and neutron flux in depth of the tissue. The dose calculation in BNCT requires four dose components, namely the alpha dose, proton dose, neutron dose, and gamma dose. The values of the alpha, proton, and gamma doses were acquired by performing a calculation of the neutron flux in depth of the tissue.

The absorbed dose was defined as the energy deposited in $1 \mathrm{~kg}$ of tissue. The neutron reaction occurred with 1 atom in the tissue. Therefore, the number of atoms in $1 \mathrm{~kg}$ tissue was acquired using Equation 1.

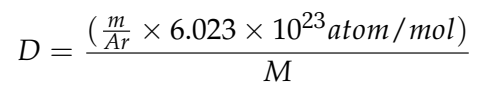

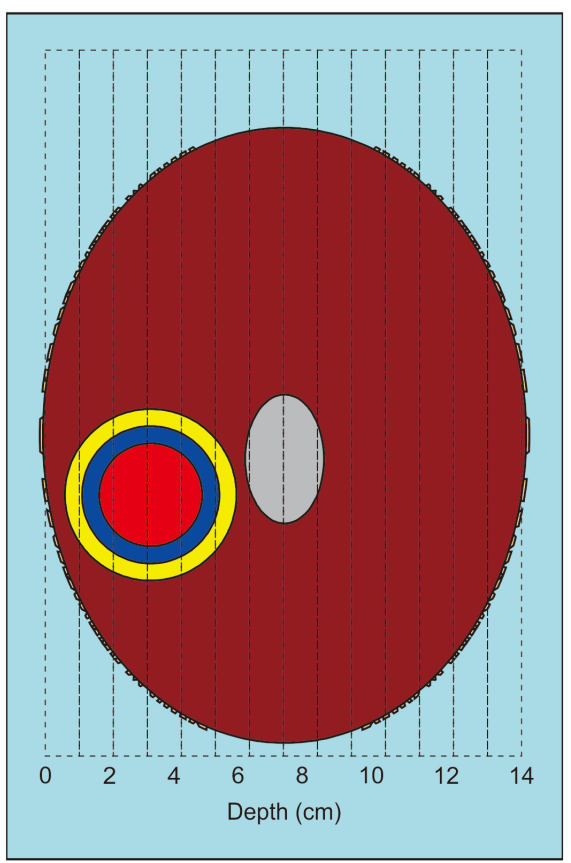

(b) Brain PTV 
After calculating the number of atoms in the tissue, the value of the dose rate was acquired using Equation 2.

$$
\dot{D}=\Phi \times N \times \sigma \times\left(E \times 1.6 \times 10^{-13} \mathrm{~J} / \mathrm{MeV}\right) x\left(1 \frac{\mathrm{Gy}}{\mathrm{J} / \mathrm{kg}}\right)
$$

where $\dot{D}$ is the value of the absorbed dose rate (Gy/s), $\Phi$ is the thermal neutron flux inside tissue (neutron $/ \mathrm{s} . \mathrm{cm}^{2}$ ), $N$ is the number of atoms in $1 \mathrm{~kg}$ tissue (atom $/ \mathrm{kg}), \sigma$ is the atom reaction cross section with thermal neutron $\left(\mathrm{cm}^{2}\right)$, and $E$ is the energy of the particle $(\mathrm{MeV})$.

The interaction between thermal neutrons and hydrogen atoms produces gamma rays. The calculation of the gamma ray dose rate started with a calculation of the release rate of the gamma rays themselves (Equation 3).

$$
\dot{R}=\Phi \times N_{H} \times \sigma_{H}
$$

where $\dot{R}$ is the release rate of gamma rays $(\gamma / \mathrm{s}), \Phi$ is the thermal neutron flux $\left(\mathrm{n} / \mathrm{cm}^{2} . \mathrm{s}\right), N_{H}$ is the number of hydrogen atoms in tissue (atom $/ \mathrm{kg}$ ), and $\sigma_{H}$ is the cross section of reaction between hydrogen and thermal neutrons $\left(\mathrm{cm}^{2}\right)$. tion 4

The gamma ray dose rate was calculated using Equa-

$$
\dot{D}_{\gamma}=\dot{R} \times \Phi \times \Delta
$$

where $\dot{D}_{\gamma}$ is the gamma ray absorbed dose rate (Gy/s), $\varphi$ is gamma ray energy fraction absorbed by tissue, and $\Delta$ is the dose rate per specific activity.

The total absorbed dose rate was obtained by adding all four absorbed dose rate components (Equation 5). The particle has a different weighting factor while radiating material.

$$
\dot{D}=\left(W_{B} \times \dot{D}_{B}\right)+\left(W_{p} \times \dot{D}_{N}\right)+\left(W_{n} \times \dot{D}_{n}\right)+\left(W_{\gamma} \times \dot{D}_{\gamma}\right)
$$

where $\dot{D}$ is the total absorbed dose rate $(\mathrm{Gy} / \mathrm{s}), W_{B}$ is the boron weighting factor (3.8 for cancer, 1.3 for healthy tissue), $\dot{D}_{B}$ is the alpha absorbed dose rate $(\mathrm{Gy} / \mathrm{s}), W_{p}$ is the proton weighting factor (3.2), $\dot{D}_{N}$ is the nitrogen or proton absorbed dose rate (Gy/s), $W_{n}$ is the neutron weighting factor (3.2), $\dot{D}_{n}$ is the neutron absorbed dose rate $(\mathrm{Gy} / \mathrm{s}), W_{\gamma}$ is the gamma weighting factor (1), and $\dot{D}_{\gamma}$ is the gamma absorbed dose rate (Gy/s).

The irradiation time was obtained by dividing the standard absorbed dose with the total absorbed dose rate (Equation 6). The standard absorbed dose to destroy rhabdomyosarcoma in children was 36 Gy.

$$
t(s)=\frac{\text { standard dose }(G y)}{\dot{D}\left(\frac{G y}{s}\right)}
$$

\section{RESULTS AND DISCUSSION}

The results of the PHITS simulation were a neutron dose in tissue and neutron flux in the depth of the tissue. Figure 3 shows the results of the PHITS simulation, which reveals the neutron flux in the depth of the tissue.

Based on Figure 3, the thermal neutrons had a maximum flux at a depth of $1.40 \mathrm{~cm}$ from the skin, which was the exact depth of the cancer tissue inside the body. This was as expected for BNCT, which relies on the interaction of thermal neutrons and boron atoms inside cancer tissue.
The particle absorbed dose rate was obtained by converting the flux neutron values in the tissues. Figure 4 shows the dose rate for each particle in body tissue. As the figure shows, the alpha dose rate had the highest value and only occurred in the PTV, CTV, and GTV, which is the cancer tissue.

The dose components for BNCT consist of four particles, namely alpha, proton, neutron, and gamma. These four particles have different weighting factors in the calculation of the total absorbed dose in the body tissue. The alpha dose component is the main component in BNCT treatment. The amount of boron compound accumulated inside cancer tissue affected the value of the absorbed dose rate for the tissue.

Figure 5 shows the relation between boron concentration in cancer tissue (GTV) and the total absorbed dose. Based on the analysis made using the OriginPro 8 program, it was found that the relation between boron concentration and dose rate was linear. Equation 7 shows the linear equation obtained from the fitting process.

$$
y=1.8879 \times 10^{-4}+\left(2.4509 \times 10^{-5}\right) x
$$

This equation could be used to get the amount of boron concentration to obtain the exact absorbed dose rate.

Figure 6 shows the total absorbed dose inside the body tissue in the head and neck region. The highest dose rate occurred in the cancer tissue (GTV) with the highest value of $1.41 \times 10^{-3} \mathrm{~Gy} / \mathrm{s}$ at a boron concentration of $50 \mu \mathrm{g} / \mathrm{g}$. The dose components received by healthy tissue were neutron, proton, and gamma doses. The value of the tissue absorbed dose rate was used to calculate the absorbed dose received by the tissue after going through irradiation time.

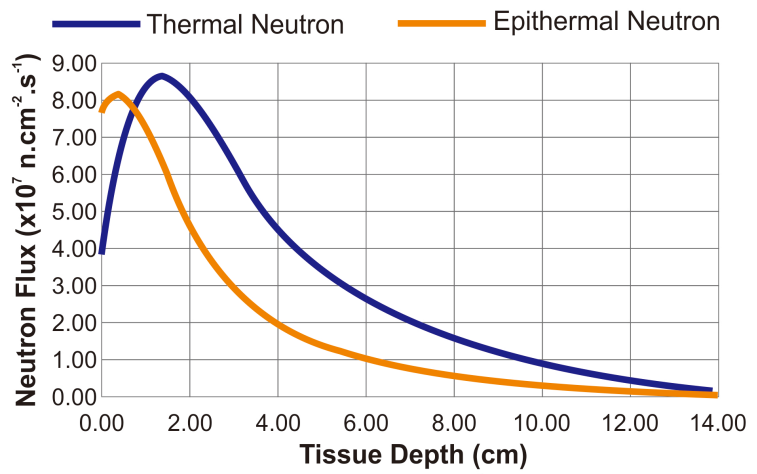

FIGURE 3. Neutron flux in depth of tissue.

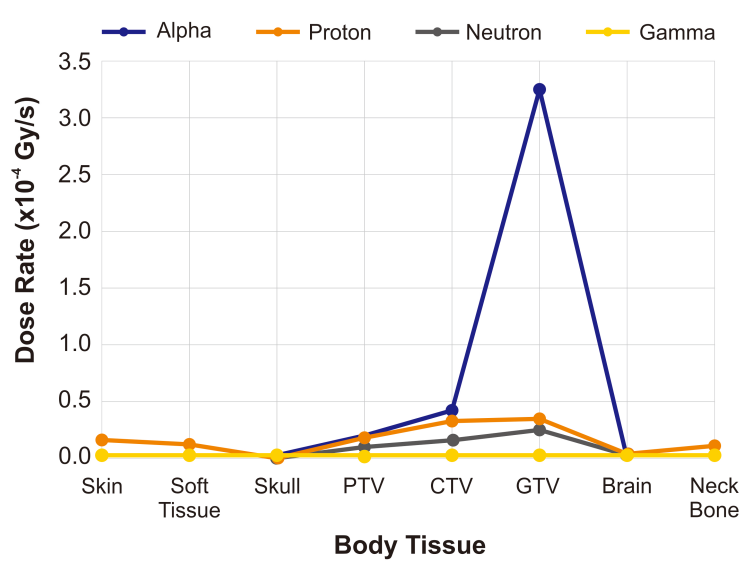

FIGURE 4. Particle dose rate. 


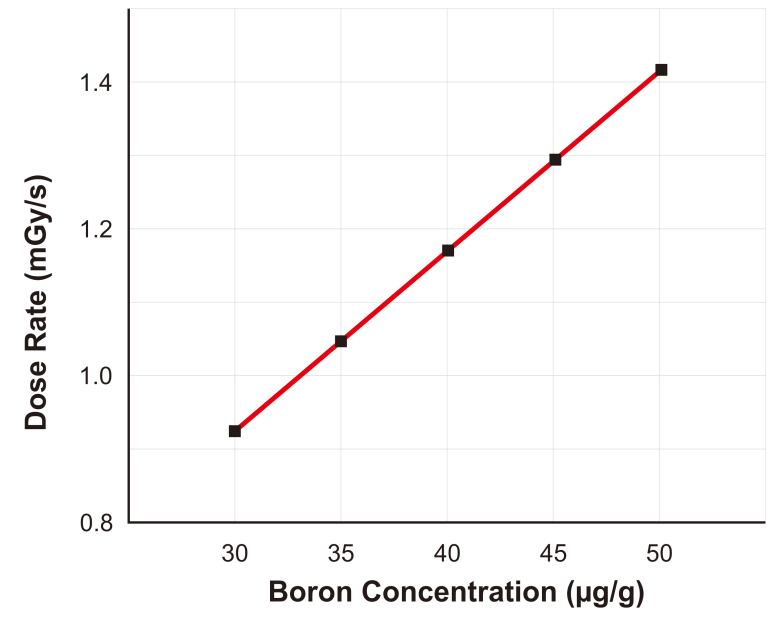

FIGURE 5. Comparison between boron concentration with total absorbed dose in the GTV.

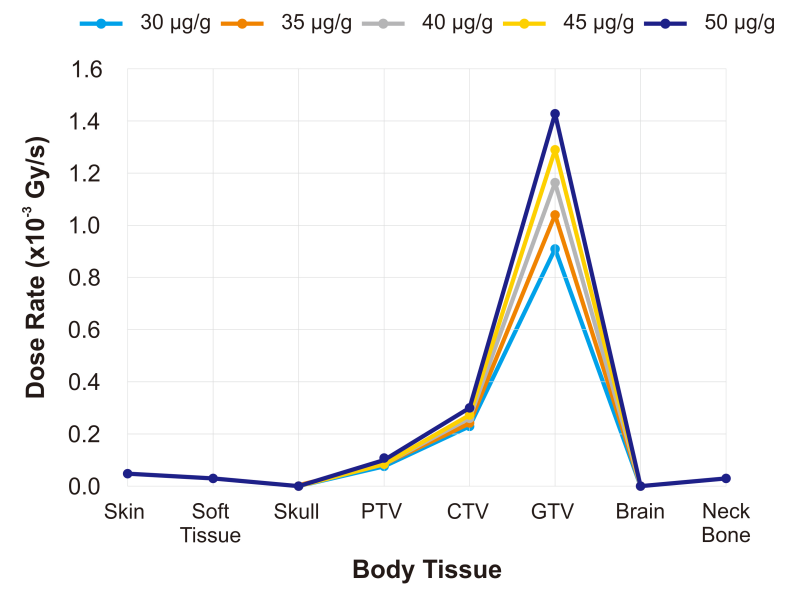

FIGURE 6. Total absorbed dose inside tissues.

The irradiation time to achieve the standard dose (36 Gy) depends on the boron concentration in the cancer tissue. The boron concentration of $30 \mu \mathrm{g} / \mathrm{g}$ needed $10 \mathrm{~h} 50$ min; $35 \mu \mathrm{g} / \mathrm{g}$ needed $9 \mathrm{~h} 33 \mathrm{~min} ; 40 \mu \mathrm{g} / \mathrm{g}$ needed $8 \mathrm{~h} 33 \mathrm{~min}$; $45 \mu \mathrm{g} / \mathrm{g}$ needed $7 \mathrm{~h} 45 \mathrm{~min}$; and a boron concentration of $50 \mu \mathrm{g} / \mathrm{g}$ needed $7 \mathrm{~h} 4 \mathrm{~min}$. Irradiation time was found to decrease with an increase in the amount of boron in the tissue, as indicated by the fact that the shortest irradiation time coincided with the highest boron concentration (50 $\mu \mathrm{g} / \mathrm{g}$ tissue).

Figure 7 shows the effect of boron concentration on BNCT irradiation time. Based on curve analysis using OriginPro 8, the relation between boron concentration and irradiation time was exponential decay. The exponential equation obtained is shown in Equation 8.

$$
y=4.38586+23.80776 e^{-(x / 22.94172)}
$$

This equation could be used to obtain the amount of boron concentration to get the effective irradiation time. The absorbance coefficient $(\mu)$ was $0.0435(\mu \mathrm{g} / \mathrm{g})^{-1}$.

The absorbed dose received by the healthy tissues was obtained by multiplying the irradiation time with the tissue's total absorbed dose rate. Skin was the sensitive part of the body when receiving radiation. Skin will turn red after receiving doses of 2-3 Gy. The boron concentration of 30 $\mu \mathrm{g} / \mathrm{g}$ and $35 \mu \mathrm{g} / \mathrm{g}$ resulted in a dose to the skin up to 1.872 Gy and 1.651 Gy. The dose received is still below the dose

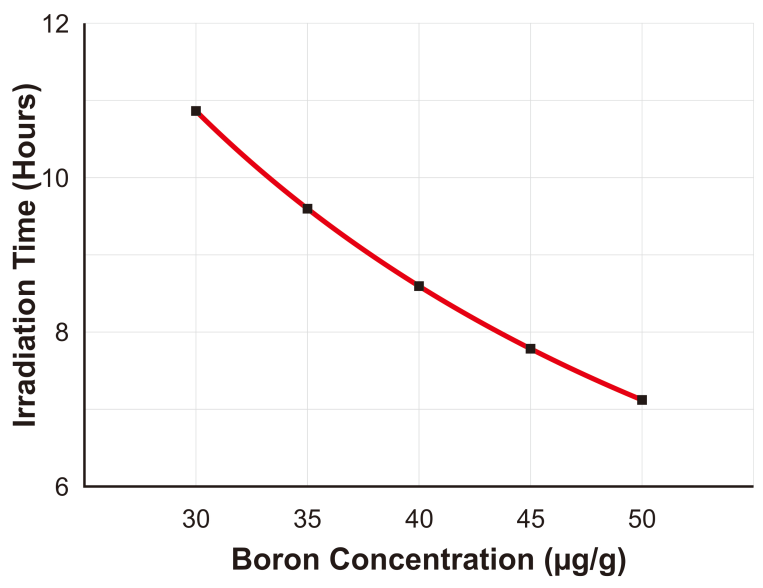

FIGURE 7. Comparison between boron concentration and irradiation time.

threshold for skin, but it has a narrow gap to the threshold dose. Therefore, the concentration that was suggested for not damaging the skin were above $40 \mu \mathrm{g} / \mathrm{g}$ tissue.

The boron concentration of $50 \mu \mathrm{g} / \mathrm{g}$ tissue had the shortest irradiation time (7 h $4 \mathrm{~min}$ ). The dose received by the skin with cancer tissue of 36 Gy was $1.221 \mathrm{~Gy}$. The healthy tissue dose at a boron concentration of $50 \mu \mathrm{g} / \mathrm{g}$ had the lowest value if compared with the other boron concentrations.

\section{CONCLUSIONS}

The optimum boron concentration among the tested doses $(30,35,4045$, and $50 \mu \mathrm{g} / \mathrm{g}$ tissue) was a concentration of $50 \mu \mathrm{g} / \mathrm{g}$ tissue. The higher the boron concentration in the cancer tissue, the higher the absorbed dose rate it received. Increasing the boron concentration also resulted in both a shortened irradiation time and reduced dose received by healthy tissue. The effective irradiation time with a boron concentration of $50 \mu \mathrm{g} / \mathrm{g}$ was $7 \mathrm{~h}$ and $4 \mathrm{~min}$.

\section{ACKNOWLEDGMENTS}

The authors would like to thank all the supporting members who helped and supported the accomplishment of the project, especially the Centre of Accelerator Science and Technology (PSTA-BATAN) for the given opportunities to perform this research and Mr. Rasito, S.T. from PTKRN BATAN for guidance in the software used in this research.

\section{REFERENCES}

Aihara T, Morita N, Kamitani N, Kumada H, Ono K, Hiratsuka J, Harada T. 2014. BNCT for advanced or recurrent head and neck cancer. Appl Radiat Isot. 88:12-15. doi:10.101 6/j.apradiso.2014.04.007.

Arrozaqi MIM. 2013. Perancangan kolimator di beam port tembus reaktor kartini untuk boron neutron capture therapy [Design of collimator in the radial piercing beam port of Kartini Reactor for boron neutron capture therapy]. Yogyakarta: Universitas Gadjah Mada. doi:10.1007/s13398-014-0173-7.2.

Barth RF, H Vicente MG, Harling OK, Kiger W, Riley KJ, Binns PJ, Wagner FM, Suzuki M, Aihara T, Kato I, Kawabata S. 2012. Current status of boron neutron capture therapy of high grade gliomas and recurrent head and neck cancer. Radiat Oncol. 7(1):146. doi:10.1186/1748-7 17X-7-146. 
Cristy M, Eckerman KF. 1987. Specific absorbed fractions of energy at various ages from internal photon sources: 7 , Adult male. Technical Report ORNL/TM-8381/V7. Oak Ridge National Laboratory. Oak Ridge.

El Demellawy D, McGowan-Jordan J, de Nanassy J, Chernetsova E, Nasr A. 2017. Update on molecular findings in rhabdomyosarcoma. Pathology. 49(3):238-246. doi:10.1016/j.pathol.2016.12.345.

Lee RJ, Lee KK, Lin T, Arshi A, Lee SA, Christensen RE. 2017. Rhabdomyosarcoma of the head and neck: impact of demographic and clinicopathologic factors on survival. Oral Surg Oral Med Oral Pathol Oral Radiol. 124(3):271279. doi:10.1016/j.oooo.2017.05.507.

Miaskowski C, Paul SM, Mastick J, Schumacher M, Conley YP, Smoot B, Abrams G, Kober KM, Cheung S, Henderson-Sabes J, Chesney M, Mazor M, Wallhagen M, Levine JD. 2018. Hearing loss and tinnitus in survivors with chemotherapy-induced neuropathy. Eur J Oncol Nurs. 32:1-11. doi:10.1016/j.ejon.2017.10.006.

Moss RL. 2014. Critical review, with an optimistic outlook, on boron neutron capture therapy (BNCT). Appl Radiat Isot. 88:2-11. doi:10.1016/j.apradiso.2013.11.109.

[NIST] National Institute of Standards and Technology. nd. Compositions of Materials used in STAR Databases. ht tps://physics.nist.gov/cgi-bin/Star/compos.pl.

Radzikowska J, Kukwa W, Kukwa A, Czarnecka A, Krzeski A. 2015. Review rhabdomyosarcoma of the head and neck in children. Współczesna Onkol. 2:98-107. doi: 10.5114/wo.2015.49158.

Reilly BK, Kim A, Peña MT, Dong TA, Rossi C, Murnick JG, Choi SS. 2015. Rhabdomyosarcoma of the head and neck in children: review and update. Int J Pediatr Otorhinolaryngol. 79(9):1477-1483. doi:10.1016/j.ijpo rl.2015.06.032.

Rosidah S, Sardjono Y, Sumardi Y. 2017. Dose analyze of boron neutron capture therapy (BNCT) at skin cancer melanoma using MCNPX with neutron source from thermal column of Kartini Reactor. Indones J Phys Nucl Appl. 2(3):111. doi:10.24246/ijpna.v2i3.111-123.

Sardjono Y, Widodo S, Irhas I, Tantawy H. 2016. A design of boron neutron capture therapy for cancer treatment in Indonesia. Indones J Phys Nucl Appl. 1(1):1. doi:10.24246 /ijpna.v1i1.1-13.

Sauerwein W, Wittig A, Moss R, Nakagawa Y, editors. 2012. Neutron Capture Therapy. Berlin, Heidelberg: Springer. doi:10.1007/978-3-642-31334-9.

Smith S, Prewett S. 2017. Principles of chemotherapy and radiotherapy. Obstet Gynaecol Reprod Med. 27(7):206212. doi:10.1016/j.ogrm.2017.04.006.

Stewart B, Wild C, editors. 2014. World cancer report 2014. International Agency for Research on Cancer.

Winocur G, Henkelman M, Wojtowicz JM, Zhang H, Binns MA, Tannock IF. 2012. The effects of chemotherapy on cognitive function in a mouse model: A prospective study. Clin Cancer Res. 18(11):3112-3121. doi:10.1158/10 78-0432.CCR-12-0060. 